\title{
Race, Language, and Schooling in Italy's Immigrant Policies, Public Discourses, and Pedagogies
}

\author{
Stephanie V. Love and Manka M. Varghese \\ University of Washington, Seattle
}

U. S. A.

In this article, we use the framework of critical race theory (CRT) to show how race, language, and schooling have played out in the historical project of the Italian nation-state. We then demonstrate how this historic racialized identity construction is currently excluding immigrants from Italian national identity. Finally, we argue that CRT can be a valuable alternative to intercultural education in that it both addresses the educational needs of immigrant and minority students in Italian schools and challenges racist and anti-immigrant discourses circulating in the broader society.

The Italian Nation-State and National Identity

The Contemporary Role of Race, Language, and Schooling in National Identity

Construction and Inclusion/Exclusion of Immigrants

Students of Immigrant Origin in Italian Schools

Intercultural Education and Critical Race Theory in Italy's K-12 Schooling

Conclusion

Notes

References

In 2011, Italy celebrated its $150^{\text {th }}$ year as a unified nation-state, creating an historic opportunity to dialogue about what it means to be Italian. While the Italian national unification project has a long, complex, and, at times, violent history, global migration and economic globalization have recently added contours to the project of building a coherent national identity. In this paper we offer a contribution to critical dialogues about immigration and national identity emerging in Italy and elsewhere through discussions on findings associated with two inquiry questions grounded in critical race theory (CRT): (a) How can CRT inform a sociohistorical analysis of the roots of policies and discourses related to immigrants in Italy; and (b) How can CRT be integrated in current education programs to support goals for inclusion and equitable access to schooling?

Although scholars have debated whether CRT developed in the United States is applicable in the European context, Moschel (2007/2008) has argued that convergence of legal, institutional, and cultural racism has made CRT analysis in Europe particularly important. CRT is built on strong and provocative tenets: racism as a permanent and not a past or contemporary aberration, a strong critique of liberalism and colorblindness, and the assertion that narrative storytelling is an important tool to understand and better the lived experiences of 
oppressed peoples and should be used as empirical data (Hill, 1999; Kubota \& Lin, 2006; Ladson-Billings, 2009; Taylor, Gillborn, \& Ladson-Billings, 2009). We argue that these three tenets are essential tools for theoretically conceptualizing and historically contextualizing racism in Italian society. The last tenet of CRT, on the value of narrative storytelling, offers perhaps the most important practical application for schools that aim to combat racism and promote understanding of the experiences of people of color and immigrants in their society.

This article is organized in four sections. First, we provide a historical discussion of how race, language, and schooling have been conceptualized in the Italian context. Second, we show how ideologies around race, language, and schooling in Italy currently function to exclude immigrants from access to critical resources. Next, we present statistics about immigrant students in Italy and their academic performance. Finally, we describe how intercultural education has been used in Italian schools and assert that CRT can be an alternative conceptual framework to address the needs of immigrant students.

\section{The Italian Nation-State and National Identity}

Critical Race Theory in its traditional form has been applied to study and critique the American welfare system, but in its contemporary permutations it has branched out to examine other structures of power such as the workings of nation-states and nationalist ideologies. We use the work of Goldberg (2002) and his book Racial State to make a case for the centrality of the nation-state in creating policies and racial categories that enforce racial exclusion and oppression, which Angel-Ajani (2000) also makes an argument for in the case of Italy. In order to understand how schools have been both implicated in, and affected by, this development of the racial state of Italy, it is critical to document how this has happened through historical and contemporary policies.

The political unit known as the nation-state is a relatively new phenomenon. In political terms, a nation refers to a community, which is tied together by a supposed "homogeneity of population" and "rootedness in the soil" (Arendt, 1968, p. 270). As nation-states began to arise as the normative and ideal political organization in Western Europe, the project of nation building was fundamental to the legitimacy of the state, which was attempted through inventing or imagining a unified national identity (Anderson, 1991; StewartSteinberg, 2007). Considering the vast diversity that defines the human experience-diversity of religion, customs, economies, languages, family structure, and political organizations, to name only a few-the production of a unified national identity was not always an easy undertaking for the nation-state (Anderson, 1991; Castle \& Miller, 2003). Italy, like most modern nation-states, did not have an easily identifiable, singular nation (homogenous in terms of language, history, and race/ethnicity) at the time of unification (StewartSteinberg, 2007). Historically, the imagined characteristics of the national identity 
helped establish superior and inferior status within the nation-state (Mills, 1997; Omi \& Winant, 1994; Stewart-Steinberg, 2007). In the case of Italy:

Italian unification was not, then, the unification of a people who shared a common culture, but of the territories of an elite who thought they shared a common culture, in a state which would then have to standardize some version of it amongst the whole population, the majority of whom were peasants (Pratt, 2002, p. 28).

As Wong (2006) shows at length in her book, Race and Nation in Liberal Italy, the construction of national identity has been, throughout most of Italy's 150 years of history, internally contested. This conflict in the concept of the nation was based on perceived differences between the peoples of Northern and Southern Italy. Drawing upon the European intellectual, political, and cultural history of race and racism, many northern Italian politicians and scholars represented the South as racially, intellectually, economically, and culturally inferior to the more "White," and therefore more civilized, North (Gramsci, 1988; Portelli, 2005). Antonio Gramsci, the famous Italian philosopher and socialist, who died while imprisoned by Mussolini's Fascist party in 1937, demonstrated how historically racialized in nature the representations of Southerners were by the hegemonic North:

It is well known what kind of ideology has been disseminated in myriad ways among the masses in the North, by the propagandists of the bourgeoisie: the South is the ball and chain which prevents the social development of Italy from progressing more rapidly; the Southerners are biologically inferior beings, semi-barbarians or total barbarians, by natural destiny; if the South is backward, the fault does not lie with the capitalist system or with any other historical cause, but with Nature, which has made the Southerners lazy, incapable, criminal and barbaric-only tempering this harsh fate with the purely individual explosion of a few great geniuses, like isolated palm-trees in an arid and barren desert. (Gramsci, 1988, p. 173)

Incidentally, the far-right-wing parties of today, like the Lega Nord that calls for the dismantling of unified Italy and the expulsion of immigrants from Italy, continue to use similar language to describe the South today.

Ideologies of race have also played a role in the rhetoric and policy decisions around the construction and contestation of Italian national identity, especially in contrast to national minorities, such as the Roma, Jews, Southern peasants of Italy, and the colonized peoples of East and North Africa (Pratt, 2002). The position of minorities in European nation-states has historically been tragically precarious-suffice it to look at the genocides, the Holocaust, and the brutality of colonial regimes of the $19^{\text {th }}$ and $20^{\text {th }}$ centuries to prove this point (Arendt, 1968). Schools during the Fascist period were also locations where students were taught the supposed profound differences between Catholic Italians and Jews, and the language around social segregation was carefully constructed and monitored (Golino, 2010). 
The absence of a standard language that all citizens spoke presented a particularly difficult problem to the building of a unified national identity in postunification Italy. As political elites attempted to politically unify the Italian peninsula under one state in 1861, widespread regional linguistic and cultural diversity made Italian identity challenging to define (Stewart-Steinberg, 2007). To address this linguistic challenge to national identity during the Fascist era, Mussolini mandated that Italian be the only language of school instruction (Wong, 2006). Yet, the insidiousness of this linguistic challenge is exemplified by the fact that it took much more than a century after the initial unification of Italy before the vast majority of Italians spoke standard Italian language as their mother tongue (Delle Valle, 2011). While racial policies during the Fascist era in Italy attempted to clearly define the Italian race as opposed to the Jewish and Roma minority, colonial subjects, and other inferior races, the Italian language was reinforced as the "language of the Italian race" (Portelli, 2005).

Policies such as the Gentile law of 1923-which mandated Italian to be the only language of school instruction-were important in establishing such links between language, race and schooling as state mandated policies. In short, schools have been places where worldviews-including racist and linguistic ideologies-were embodied, performed, and enforced. Schools have been such an important institution in nation-state building projects that it is no coincidence that schooling was made mandatory only a few years before the unification of Italy (Gramsci, 1988). As Stewart-Steinberg (2007) demonstrates, schools were considered so central to the notion of Italian nationhood that the fathers of the national building project imagined that "the site where geographical Italy (was) to be transformed into a nation (was) the school...The school must provide a training in nationhood, just as the nation itself must function as a great school" (p.17). Significantly, after unification, publicly funded secular schools were often built as a democratic and liberal challenge to the earliest institutions of education in Italy, most notably those founded by the Catholic Church (Gramsci, 1988; Kowalczyk \& Popkewitz, 2005).

Contemporary migratory patterns have also affected the conceptualization and contestation of the Italian nation-state and national identity. Global migration-through processes of emigration, immigration, and internal displacements-has helped shape contemporary Southern Europe and the rest of the continent (Calavita, 2005; Castle \& Miller, 2003). Between the $17^{\text {th }}$ and the $20^{\text {th }}$ centuries, White Europeans immigrated in mass to the new nations of the Americas and Australia. They also endured massive internal migrations due to political conflict, oppression, and economic inequality that caused large waves of refugees and internally displaced persons (Arendt, 1968). Yet, it has mainly been since World War II (and increasingly so since the 1980s and 90s) that large waves of migrants started to come from outside of the traditional Europe to stay, and since then migration has exploded rhetorically into one of the most important phenomena on the political stage of Europe (Calavita, 2005). Changes in the global economy and the increase in non-traditional political conflicts have also significantly altered the nature and scope of migration (Castle \& Miller, 2003). Importantly, this means that immigrants in Europe today are even more diverse 
in terms of race, class, and gender, as well as educational, personal, and linguistic backgrounds, than ever before.

As mass media representations and political discourses on the role of immigrants in Western countries show us, the contemporary systems of global migration have had serious consequences for the conceptualization of national identity and the validity of the political unit of the nation-state (Angel-Ajani, 2003; Arendt, 1968; Calavita, 2006; Castle \& Miller, 2003). This is particularly telling when we consider the current crises and polemics in many European countriesfrom Germany to England to Italy —over the supposed failure of multiculturalism. The reality of the historical roots and contemporary realities of increasing racism, xenophobia, and discrimination in Europe are much more complicated than the failure of a multicultural policy, as we will show in the next section.

\section{The Contemporary Role of Race, Language and Schooling in National Identity Construction and Inclusion/Exclusion of Immigrants}

In the contemporary context of Italy, and of Europe more generally, there is growing evidence that race still plays a very important role in social and political inclusion and exclusion (Balbo \& Manconi, 1992; Calavita, 2005; Khouma, 2010; Moschel, 2011; Peri, 2009; Wong, 2006). Yet, in Italy, many scholars and politicians prefer the term ethnicity over the taboo term of race to describe differences between White Italians and non-White Italians, minorities, and immigrants. This preference most likely stems from the stigmatization of the word race after the end of the Fascist race laws of the 1930s and 1940s. Skeptics of the use of the term "race" (rightfully) state that race does not exist in any biological sense; yet, they further argue that the use of the term by academics, politicians, and activists might serve the purpose of reinforcing the notion of race in society and therefore they opt for a "colorblind" approach to difference (Moschel, 2011). This approach has stymied a discussion on whether politics and policies have racist motivations and whether institutional racism has been codified into law.

The Italian version of institutional racism and race-based discrimination against minorities, immigrants, and mixed-race individuals is a compilation of economic marginalization, housing discrimination, police and judicial discrimination, exclusion of racialized non-Italians from Italian citizenship, and, as we will suggest, lack of access to resources such as a quality basic and higher education (Calavita, 2005, 2006; Murie \& Musterd, 2004). Scholars such as Angel-Ajani $(2000,2003)$ and Calavita (2006) have highlighted the particularly nefarious harassment that people of color, particularly migrant women, experience in the hands of Italian police and people in other authority positions. The criminalization of race and the racialization of criminality have led to a large percentage of those convicted of crimes and inmates in Italian prison to be of immigrant origin. Moreover, racism and discrimination towards immigrants, people of color, and minorities (such as the Roma and Sinti) have been 
exemplified by the increasing incidence of race-motivated violence in Italy and the government's unwillingness to acknowledge such a crisis (Human Rights Watch, 2011). In addition, growing evidence also points to significant discrimination in the housing market, amounting to excessively higher rents, deteriorating conditions, overcrowding, and "landlord resistance against renting to foreigners at a normal market price" (Dell'Olio, 2004, p. 120). This discrimination also includes less straightforwardly racist policies, such as language and citizenship policies that may appear neutral, but in fact are rife with issues of race-based discrimination.

Recently, language has reemerged as a focus in the politics of Italian national identity. In a telling political move reflecting perceived encroachments of foreigners on Italian national identity, the government made Italian the official language only in 2007. This push towards linguistic nativism is especially problematic when one considers that article 6 of the Italian constitution protects the rights of minority language speakers in Italy. ${ }^{1}$ This contradictory language policy begs an obvious question: Why in the early $21^{\text {st }}$ century did politicians find it necessary to enact a nationalist language policy, tying the Italian language to Italian national identity? What are the political motivations for such a change at this point in history? How does such a policy impact the ways that groups of people are included and excluded from national identity?

As in a number of European countries, the proficiency in the national language has become highly politicized and is now being considered a necessary prerequisite to residency and citizenship (Burns \& Roberts, 2010). In December of 2010, a law was enacted, which requires anyone applying for a long-term residency permit (permesso di soggiorno di lungo periodo or carta di soggiorno) to pass a written Italian language test that satisfies the European standard of A2. ${ }^{2}$ This new law has caused intense debate and confusion ever since it was passed. The fact that the test is a written, not oral, test raises questions of exclusion for those who may be illiterate, have difficulties writing and reading, or speak the local dialect instead of standard Italian. This is not to mention the frustrations that will inevitably follow this new bureaucratic obstacle to legal residency permits. The issue of legal residency permits has become an infamously arduous, confusing, and at times slow process since the Bossi-Fini immigration law of 2002 requires that immigrants reapply for their permanent residency every five years and short-term residency every two years. As Lakhous (2010) argues, these types of bureaucratic obstacles exemplify the contemporary version of institutional racism in Italy.

Borrowing the concept from Ashcroft (2001), we suggest that the language around immigration in Italy "exists as much to conceal as to signify" (p. 312), reflecting a language ideology that marks the racial parameters of Italian national identity (Faso, 2008; Woolard \& Schieffelin, 1994). The terminology that refers to individuals and groups that are not considered to be racialized as Italiani or White Italians is very limited on the one hand, and very loaded on the other. Straniero, or foreigner, is a term that is more or less used indiscriminately to refer to anyone who is not perceived to have Italian blood. Even second generation, adopted, 
and sometimes mixed race children (especially if they cannot "pass" as White) are referred to as foreigners in everyday discourse (Ambrosini, 2009). Most importantly, this is true even legally speaking, since, as Andall (2002) demonstrates, "migrants' children assume their parents' nationality until they reach the age of majority. This means that a recently-arrived 16-year-old from Sierra Leone is statistically indistinguishable from a 16-year-old of Sierra Leonean origin who was born in Italy" (p. 390). The difference between the concept of the real Italian and the foreigner therefore aids in the linguistic compartmentalization of who belongs and who does not belong to the national identity through both legal classification and everyday speech.

With large influxes of immigrants that are visibly different from racialized White Italians, race takes an even more relevant meaning for national identity when one considers citizenship law (Balbo \& Manconi, 1992). Italian citizenship laws have reinforced the link between the notion of Italian blood and national membership, favoring ius sanguinis (citizenship by blood) in contrast to ius soli (citizenship by birth in a territory) (Andall, 2002). When a child is born in Italy to parents who are not Italian citizens, he/she is considered an immigrant until he/she can apply for citizenship at 18 (Calavita, 2005; Lakhous, 2010; Marinaro \& Walston, 2010). Yet, citizens of other countries, who can prove that they have a relative (e.g., grandfather) who had Italian citizenship, can acquire citizenship rather easily, even if they don't speak Italian. So interestingly, if you have Italian blood, speaking the Italian language is not a requisite for citizenship, but if you are requesting a permanent residency permit because you live and work in Italy, language is now a prerequisite for your long-term legality.

Scholars of race in Italy have also asserted that it appears that being Black and being Italian are mutually exclusive (Andell, 2002; Calavita, 2005; Khouma, 2009). Powerful personal stories of the harassment and exclusion that Black Italians experience in Italy are increasingly common and disheartening. The now infamous aggression toward the Black Italian football player, Mario Balotelli, is a frightening sign that racism is returning to the public space in ways that mirror the violent racism of Europe's past. When Italian ultra right-wing "football" (soccer) fans make banners and chant slogans like "a Negro cannot be Italian" (un negro non può essere italiano) and make monkey noises at Balotelli and other Black football players when they are in control of the ball, they are making a clear racial link, whether they know it or not, between contemporary italianità (Italianness) and historical racism and racialization.

Authors and scholars of color in Italy, like Pap Khouma in his powerful book of narrative essays, Noi Italiani Neri: Storie di Ordinario Razzismo (Us Black Italians: Stories of Ordinary Racism) (2010), are beginning to shine light on the problem of race that some scholars and policy makers have thought to be of a particular American quality. Even the Italian government, as a recent Human Rights Watch report highlights, rejects the idea that racism and racially motivated violence is a problem in Italy, in denial of the startling evidence to the contrary (Donadio, 2010; Human Rights Watch, 2011). 
Schools are also becoming locations of increasing political debate around Italian identity in the age of migration as they were in the era of the formation of the nation-state. Mass media outlets, politicians, and public opinion have referred to large numbers of foreign students (seemingly regardless of whether these students are born in Italy) in schools, the ghettoization of foreigners, and what has been termed the takeover of community schools by non-White Italians and foreigners. These discourses have, in turn, elicited political responses. The Gelmini law of 2009, which limits the number of foreign students (read: nonWhite students) to $30 \%$ in each classroom (Grattoggi, 2010), appears to be an attempt to guarantee that these students are exposed to what they believe are native Italian speakers to facilitate standard language acquisition. While there is no doubt that the learning of Italian is an important goal of education for immigrant and minority students in Italy, this law effectively labels immigrant children as a problematic group whose presence must be regulated by law. In addition, many of these children already speak fluent Italian. The law also reflects the political preoccupation with supposed ethnic ghettos and takeovers of local schools by immigrant families (Valentini, 2005).

\section{Students of Immigrant Origin in Italian Schools}

According to the 2011 Dossier Statistico Immigrazione of Caritas/ Migrantes, foreign students made up $7.9 \%$ of the total number of enrolled students $(709,826$ students total) in the Italian K-12 school system. This average saw its peaks in the regions of the Northeast at $12.4 \%$ and the lowest levels in the Southern Islands at $2.2 \%$ of the student body. The countries of origin that constitute the largest chunk of all enrolled foreign K-12 students in Italy are Romania (17.8\% of all foreign students), Albania (14.0\%), Morocco (13.0\%), and to a lesser extent China (4.6\%). Countries of origin that make up between $1.5-3 \%$ of the K-12 foreign student body include The Maldives, India, The Philippines, Ecuador, Tunisia, Ukraine, Macedonia, Peru, Pakistan, Serbia and Montenegro, and Egypt. It is important to note that $42.2 \%$ of all those characterized as foreign students in Italian K-12 schools were born in Italy to parents with foreign citizenships.

In contrast to the K-12 study body, students with foreign citizenships make up only $3.6 \%$ of all enrolled students in Italian universities ${ }^{3}$ (Caritas/Migrantes, 2011). This number is not very surprising when one considers that seven out of ten students of immigrant origin end up in technical or professional schools instead of college-bound licei. Scholars have noted that reasons for low collegebound secondary and university participation of students of immigrant origin are complexly correlated with the economic and social choices and strains of the working-class and underclass employment of migrants in Italy (Bertolini, Lalla, \& Toscano, 2010; Caritas/Migrante, 2011). The Caritas report aptly states:

In a society in which adults of immigrant origin occupy a marginal position, do the most unskilled and least paid work, live in small and inadequate 
housing, and have to subordinate themselves to choices that prioritize the renewal of their permesso di soggiorno, to enroll their children in university, or even to imagine it, becomes a luxury reserved for the few. (pp. 180-181, our translation)

The difficulty for students of immigrant origin in attending university is linked to an emerging disparity in school performance in Italy for first, second, and third generation minority students in Italy. In 2011, the Foundazione ISMU along with the Ministry of Instruction, University and Research (Ministero dell'Istruzione, dell'Università e della Ricerca or MIUR) published some alarming statistics on foreign students' performance in Italian K-12 school system. One of the most telling statistics in this report is the number of foreign students that are not in classes that correlate with their age (alunni in ritardo scolastico), either by being held back during the schooling process or originally being placed in lower grades due to their linguistic and academic history and achievement. A total of $18.2 \%$ of foreign primary school students are not in grades that correlate with their age (compared to $2.0 \%$ of their peers with Italian citizenship), $47.9 \%$ of foreign middle school students (compared to $8.5 \%$ of their peers with Italian citizenship), and a staggering $70.6 \%$ of foreign students in upper secondary school, or high school (compared to $25.1 \%$ of their peers with Italian citizenship). It must be noted that these numbers have begun to fall (albeit slowly) from previous years, which according to the authors of the Foundazione ISMU report can be attributed to more and more foreign students born in Italy and completing all their schooling in Italy. Most importantly, these statistics show that regardless of the governmental integration policy recommending that students should be placed in classes that reflect their age, the reality is that a large percentage of foreign students are not participating in schooling with their age-peers but instead are placed in classrooms that supposedly reflect their "level of proficiencies and abilities" (Foundazione IMSU, 2011, p. 43).

In another study published in Other Modernities in 2009, it was noted that foreign students are failed more often, abandon their studies, receive lower grades, and end up in brief professional programs instead of university more than their peers born to two White Italian parents (Ambrosini, 2009). While the reasons for this disparity in educational performance and access needs to be studied in greater depth in Italy, similar studies in the United States have pointed to institutional factors, like higher levels of poverty, poorer neighborhood and school conditions, and cultural disconnects between teachers and students (Apple, 2004; Leonardo, 2009; Valenzuela, 1999) as being associated with access and performance disparities. Further research might be able to individuate some of the reasons for these discrepancies in order to highlight what role institutional racism inside and outside the school walls plays in these disparities for immigrant students. 


\section{Intercultural Education and Critical Race Theory in Italy's K-12 Schooling}

In 1989, the Italian Ministry of Public Instruction (Ministero della Pubblica Istruzione, 2007) issued its first decree regarding the "reception and integration" of "immigrant students" in the Italian school system, regulations that came into effect in 1990. Over these 20 years, intercultural educational policies have changed significantly as migration to Italy has increased and the politics of immigration have become more central on the national stage (Byran, 2009; Favaro \& Luatti, 2004; Liddicoat \& Diaz, 2008; Malta, 2010; Ricucci, 2008). Yet, it was not until 2006 that the Ministry called for the creation of a National Center for the Integration of Foreign Students and Intercultural Education (Osservatorio Nazionale per l'Integrazione degli Alunni Stranieri e per l'Educazione Interculturale). This initiative was composed of leading academics, cultural mediators, and non-profit and civic organizations that were engaged in the conversation around immigration, schooling, and the changing Italian society (Ministero della Pubblica Istruzione, 2007).

In October of 2007, this National Center published its recommendations in La Via Italiana per la Scuola Interculturale e I'Integrazione degli Alunni Stranieri: Osservatorio Nazionale per l'Integrazione degli Alunni Stranieri e per l'Educazione Interculturale (The Italian Way for Intercultural Schooling and the Integration of Foreign Students: National Center for the Integration of Foreign Students and Intercultural education). This document can be seen as the official governmental policy for what is being called the new multicultural landscape of Italians schools, as it was published by the Ministry of Public Instruction (Ministero della Pubblica Istruzione) and signed by the Minister, Giuseppe Fiorini. The policy calls for the integration of intercultural worldviews and methods at every point in the schooling process from curriculum choices to the interactions between teachers, staff, parents, and students. Therefore, an in-depth look at this policy is necessary to understand the ideology behind intercultural education, the suggested methods for implementation, and the financial and academic support and feasibility in Italy.

The Italian Way for Intercultural Schooling and the Integration of Foreign Students (Ministero della Pubblica Istruzione, 2007) calls for a professional, uniform, and organized acknowledgement of the "enrichment" that migrants bring to Italian schools as well as a response to the preoccupations around the presence of foreign students in Italian schools (p. 3). The goal is not only to integrate foreign students, but also to increase mutual understanding in all aspects of the schooling process, therefore, for both native and foreign students, teachers, staff and parents. It further calls for using the classroom and school as a stage to reinforce the importance and acknowledge differences in order "to reduce the risk of standardization or assimilation" (p. 8, our translation) of foreign students into mainstream culture. In one of its most important directives, the 
policy aims to avoid separate classes for Italian language learning students and, instead, to integrate language teaching and learning into the normal rhythms of the average classroom. This approach is already utilized in Italian schools for students with learning, emotional, and physical disabilities.

The Italian Way for Intercultural Schooling and the Integration of Foreign Students offers some reflection on the "value of plurilingualism" and reinforces the Italian public schools' priority of language of origin in its education policy. In fact, it states that:

The maintenance of the language of origin is a human right and a fundamental instrument of cognitive development, with positive implications also for [Italian as a second language] and [other foreign languages] learned in school (Ministero della Pubblica Istruzione, 2007; p. 13, our translation).

In conformity to new EU integration goals, the European languages of French, Spanish, German, English, and Russian are already offered to students. This report calls for further consideration towards minority languages that are spoken by students from immigrant backgrounds. Official rules towards the teaching of minority languages were further expanded upon by the Ministry in $2009,{ }^{4}$ in a financial project designed to promote intercultural dialogue through language learning as an essential feature of a multilingual Italy (rich in dialects and local variations), participation in the multilingual Europe, and for communication with migrants and foreigners in Italy.

While the Italian Ministry of Public Instruction asserts a dedication to the teaching and support of minority languages in the Italian preK-12 school system, the specifics of such a policy are at best unclear. It states that individual schools can and should teach the minority languages that represent their unique student population if they teach the standard version of that language. The policy even allows schools to teach other core subjects in the minority language outside of language class to buttress more effective learning. Yet, nowhere in these documents is the method of bilingual education mentioned, even with the goals of pluralingualism stated throughout. In fact, as Liddicoat and Diaz (2008) have argued, "as the focus of policy language-in-education has broadened, the position of immigrant languages and immigrant learners has been increasingly marginalized and the specific educational needs of immigrant children have been relegated to the background against wider educational goals and adherence to the European agenda" (p. 148). In summary, the Italian official migrant language education policy does not require that schools teach such languages of immigrant origin, but instead allows them to implement such a policy if the individual school takes the initiative. Therefore, there is unlikely to be a nationwide, coordinated campaign for bilingual and biliteracy education for children from immigrant origin in languages that reflect their own heritage and community.

While the "Italian way" of intercultural education is a strong statement of dedication to the building of an inclusive K-12 schools system, there are some major problems in its theory as well as concerns reflected in practical issues of 
student achievement. In fact, there is a surprising lack of discussion in this document of the current disparities in student school performance, ageappropriate grade-level enrollment, and college readiness. In this sense, the integration of students as referred to in Italian intercultural education appears to be more about social relations and dialogue than about school preparing students from migrant origin to participate in Italian society and in the economy and political system. Adding to this concern about school access and performance might be the concern that intercultural education turns a "blind-eye" to the reality that the Italian economy relegates many immigrant adults to the most marginal, precarious, and dangerous jobs and positions in society (Calavita, 2004; Caritas/Migrantes, 2011). The question remains, "Will the children of immigrants raised in Italy also be expected to fill the jobs that are undesired by 'native' Italians but considered necessary for the functioning of their economy?" With 7 out of 10 students from immigrant backgrounds attending non-college bound professional and technical secondary schools, entry into the middle and professional class may be unlikely (Caritas/Migrantes, 2011).

We argue that the area that is most troubling in Italian intercultural education is a superficial treatment of issues of racism in Italian society and schooling system. In fact, The Italian Way for Intercultural Schooling and the Integration of Foreign Students (Ministero della Pubblica Istruzione, 2007) begins its small section on "intervention against discrimination and prejudice" by stating, "the presence of immigrants in schools can bring forth certain 'natural' and common mechanisms in all people related to ethnocentrism, such as trying to render more similar the behavior and actions of those from the same category, while highlighting the differences of others from groups that appear different" ( $p$. 15). The statement continues that anti-racism should be a principal goal of intercultural education even if the term race is never used. The official Italian version of intercultural education focuses on reconciling differences and removing the veil of the other in order to promote integration of immigrant students and decrease incidences of prejudice and stereotyping. Yet, it appears that intercultural education, like all educational policies, is the product of political trends and opinions, which may reflect non-neutral worldviews (Apple, 2004). In the contemporary anti-immigration political climate of Italy, it becomes more apparent that the politics of intercultural education, which focus on the value of differences and similarities between cultures, do not address the lived experiences of xenophobia and racism in Italian society.

Most importantly, the racism, prejudice, and discrimination addressed by Italian intercultural education is not contextualized, rendering it visible only as a phenomenon of the changing multicultural society rather than being rooted in a long history of race and linguistic based nationalism as we have demonstrated earlier in this article. We argue that adapting the framework of critical race theory (CRT)—adjusted to the specifics of the Italian context—could help demonstrate that racism and discrimination have a historical and more permanent position in Italian society, as we have shown in our introductory sections. This also means that racism and race-based othering and discrimination are not going to disappear by themselves, even with more intercultural dialogue in schools and 
society. Instead, there must be more targeted action, through schooling and other social forums, to combat an exclusive Italian national identity. CRT as a framework, rather than Intercultural Education, may help to address this.

CRT praxis aims to "[challenge] dominant ideology while maintaining a commitment to social justice and valuing experiential knowledge" (Stovall, Lynn, Danley, \& Martin, 2009). Bringing counter-narrative voices forward is a central goal of CRT and can also be a valuable technique in the classroom. Research suggests that it helps to involve students in ways that standard pedagogy might not and can inspire students to see schooling as something that reflects and will better their own experience (Ladson-Billings, 2009; Romero, Arce, \& Cammarota, 2009; Sleeter \& Delgado, 2004; Taylor, Gillborn, \& Ladson-Billings, 2009; Valenzuela, 1999). As one CRT practitioner in the United States writes, "Applying critical race theory to the classroom provides one way to ensure that structures are in place to validate student experiences while arming us with the skills needed to transform our own lives" (Knaus, 2009). This includes the strengthening of academic skills such as reading, writing, and critical thinking through engaging with the counter-narratives of those who have experienced discrimination, racism, and lives different from the mainstream.

In Italy, there has hardly been any application of CRT pedagogically compared to countries such as the United States and Great Britain. However, the study of counter-narratives known as migrant literature has addressed many similar themes. Graziella Parati (2005), one of the leading scholars in the emerging field, shows that migrant literature in Italy (or literature written by migrants who learn Italian as a result of their migration and begin to write in the language) is a valuable form of "talking back" to the dominant culture that aims to racialize migrants as the other and homogenize Italian culture as White and European. She argues that, while short of full-blown resistance (as some writers of color have started doing in countries like France), migrant writers are bringing forth counter-narratives that oppose the imagined White European Italian as fundamentally different from the non-White migrant. This emergence of counternarrative storytelling by Italian authors of color could provide students with curricular content that reflects the real diversity of Italy and could inspire students to create their own counter-narratives that oppose the supposed cultural and racial homogeneity of its population.

A major challenge to adapting the CRT framework in mainstream Italian schools is the divergence between the lived experiences of the teachers and those of the students. In Italy, as in the United States, many teachers come from backgrounds that reflect more of the mainstream society, speak standard Italian, are citizens, and belong to the ascribed identity of White Italians. On the other hand, a growing number of pupils come from different experiences, many including poverty, racism, and complex migrant histories. It is hard to imagine how teachers can effectively implement and execute such a rigorous intellectual framework, especially with provocative topics around race and racism, without opportunities for dialogue and study themselves. 
The educational researchers of critical teacher training have noted that many of the same approaches that may be appropriate in the classroom also apply to teacher education. "Diversity study circles" (Moss, 2008) have been used to facilitate critical interaction between teachers who come from the mainstream and educators and students from minority, socio-economically disadvantaged, and migrant backgrounds. Much like CRT praxis for the classroom, teacher educators could incorporate literature from authors of different backgrounds, including authors who have experienced racism, discrimination, poverty, and migration (Katsarou, 2009) into teacher education and professional learning programs.

\section{Conclusion}

In this article we looked at the historical relationship of language, race, and schooling to the nation and national identity building process in Italy by using a CRT framework. We argued that it is through analyzing such historical links that one can start to understand the role that language, schooling, and race play in the discourses around the national membership of immigrants, refugees, and minorities. Race has played a central role in the construction of Italian national identity and remains today an ideology that strongly impacts the ways in which individuals interact in society. Language serves many foundational and often contradictory functions in the politics and processes of national identity and nationalism. Some scholars have, in fact, argued that language operates to inscribe instead of describe social differences and inequality (Ashcroft, 2001). Schooling has furthermore been a central location in the making of Italians as well as monitoring and enforcing language and racial ideologies. This understanding needs to be integrated in the philosophy and pedagogy of schooling in Italy by demonstrating that institutional racism-with its links to race, language, and schooling-fundamentally impacts the experience of immigrant groups in Italy. Thus, combating and answering back to institutional racism must be at the center of any pedagogy focusing on social justice for minority/underrepresented groups. The article concludes by arguing that the intercultural approach to educating new immigrants, refugees, and their children could fail at its task if scholars and teachers do not bring an understanding of the historical circumstances of institutional racism into the center of their work with immigrant and nonimmigrants in schools. CRT, through the use of narrative as an essential way of knowing oppression as well as its historical and theoretical understanding of institutional racism, is a potentially helpful framework and methodology in the classroom, in professional learning for teachers and for educational research - especially in working with immigrant students, their peers, and their teachers. 


\section{Notes}

1. Art. 6 of the Constitution of Italy: La Repubblica tutela con apposite norme le minoranze linguistiche. (The Republic safeguards linguistic minorities with special rules).

2. La Repubblica, one of the most important daily newspapers in Italy published an example of the test. See test at http://firenze.repubblica.it/ cronaca/2011/ 01/17/foto/leggi_la_prova_del_test_di_firenze-11323204/1/

3. This above number includes many international students who did not complete their K-12 education in Italy. Albanians make up $20.2 \%$ of all foreign university students, with China next at $7.4 \%$, Romania at $6.8 \%$, Greece at $5.8 \%$, Cameroon at $3.8 \%$, and Morocco at $2.6 \%$ of all foreign university students in Italy.

4. While some "foreign" students who completed their K-12 schooling in Italy apply and are granted citizenship at 18 and therefore become merged with "native" Italian students in educational statistics, both the Caritas and the Minister of Public Instruction 2011 reports note complex obstacles for students from immigrant families to continuing on to university after completing K-12 schooling.

5. See a Minister's memo Circolare no. 70, MIUROODGOS prot.n. 8100/R.U./U as found at http://www.istruzione.it/web/istruzione/cm70_09

\section{References}

Ambrosini, M. (2009). Nuovi concittadini? I giovani di origine immigrata, vettore di cambiamento della società italiana [New co-citizens? Youth of immigrant origin, vector of change in Italian society]. Altre Modernità: Università degli Studi di Milano, 2(10), 20-28.

Andall, J. (2002). Second-generation attitude? African-Italians in Milan. Journal of Ethnic and Migration Studies, 28(3), 389-407.

Anderson, B. (1991). Imagined communities: Reflections on the origin and spread of nationalism. New York, NY: Verso.

Angel-Ajani, A. (2000). Italy's racial cauldron: Immigration, criminalization and the cultural politics of race. Cultural Dynamics, 12(3), 331-352.

Angel-Ajani, A. (2003). The racial economies of criminalization, immigration, and policing in Italy. Social Justice, 30(3), 48-62.

Apple, M. (2004). Ideology and curriculum ( $2^{\text {nd }}$ ed.). Boston, MA: Routledge \& K. Paul. 
Arendt, H. (1968). The origins of totalitarianism ( $2^{\text {nd }}$ ed.). Orlando, FL: Houghton Mifflin Harcourt.

Ashcroft, B. (2001). Language and race. Social Identities 7(3), 311-328.

Balbo, L., \& Manconi, L. (1992). I razzismi reali [Real racisms]. Milano, Italy: Giangiacomo Feltrinelli Editore.

Bertolini, P., Lalla, M., \& Toscano, V. (2010). L'inserimento scolastico degli studenti stranieri di prima e seconda generazione [School adaptation for first and second generation foreign students]. CAPP-Centro di Analisi delle Politiche Pubbliche, 78,1-27.

Burns, A., \& Roberts, C. (2010). Migration and adult language learning: Global flows and local transpositions. TESOL Quarterly, 44(3), 405-419.

Byran, A. (2009). The intersectionality of nationalism and multiculturalism in the Irish curriculum: Teaching against racism? Race Ethnicity and Education, 12(3), 297-317.

Calavita, K. (2005). Immigrants at the margins: Law, race and exclusion in southern Europe. Cambridge, UK: Cambridge University Press.

Calavita, K. (2006). Gender, migration, and law: Crossing borders and bridging disciplines. International Migration Review, 40(1),104-132.

Caritas/Migrantes (2011). Dossier Statistico Immigrazione: $21^{\circ}$ Rapporto. Rome, Italy: IDOS-Redazione Dossier Statistico Immigrazione Caritas/Migrantes.

Castle, S., \& Miller, M. J. (2003). The age of migration. New York, NY: Guilford Press.

Delle Valle, V. (2011, March 19). II viaggio fra le lingue [The journey through languages]. II Manifesto, p.10.

Dell'Olio, F. (2004). Immigration and immigrant policy in Italy and the UK: Is housing policy a barrier to a common approach towards immigration in the EU? Journal of Ethnic and Migration Studies, 30(1),107-128.

Donadio, R. (2010, January 10). Race riots grip Italian town, and Mafia is suspected. The New York Times, p. A7.

Faso, G. (2008). Lessico del razzismo democratico: Le parole che escludono [The lexicon of democratic racism: Words that exclude]. Romo, Italy: DeriveApprodi.

Favaro, G., \& Luatti, L. (2004). L'intercultura dalla A alla Z [Interculturality from A to Z]. Milano, Italy: FrancoAngeli.

Foundazione ISMU (2011). Alunni con cittadinanza non italiana: Verso l'adolescenza [Students with non-Italian citizenship: Towards adolescence]. Quaderni Ismu, 4.

Goldberg, D. T. (2002). The racial state. Oxford, UK: Blackwell. 
Golino, E. (2010). Parola di Duce: Il linguaggio totaliario del fascismo e del nazismo [Words of the "Duce": The totalitarian language of Fascism and Nazism] $\left(2^{\text {nd }}\right.$ ed.). Milano, Italy: RCS Libri \& Grandi Opere S.p.A.

Gramsci, A. (1988). An Antonio Gramsci reader. D. Forgacs, (Ed.). New York, NY: Schocken Books.

Grattoggi, S. (2010, September 12). Roma, ecco la classe prima B. Gli alunni sono tutti bambini immigrati [Rome, here is the class $1 \mathrm{~B}$. The students are all immigrant children]. La Repubblica. Retrieved from http://www.repubblica.it/scuola/2010/09/12/news/roma_ecco_la_prima_b_ classe_con_tutti_bambini_immigrati-6989763/index.html?ref=search

Hill, J. H. (1999). Language, race, and white public space. American Anthropologist, 100(3), 680-689.

Human Rights Watch. (2011). Everyday intolerance: Racist and xenophobic violence in Italy. New York; Human Rights Watch. Retrieved from http://www.hrw.org/en/reports/2011/03/20/everyday-intolerance-0

Katsarou, E. (2009). Reading African-American literature to understand the world: Critical race praxis in teacher preparation. Race, Ethnicity and Education, 12(2), 253-266.

Khouma, P. (2009, December 12). Io, nero italiano e la mia vita ad ostacoli [I, Italian Black and my life hurdles]. La Repubblica. Retrieved from http://www.repubblica.it/cronaca/2009/12/12/ news/io_nero_italiano_e_la_mia_vita_ad_ostacoli-1820188/

Khouma, P. (2010). Noi italiani neri: storie di ordinario razzismo. [Us black Italians: Stories of ordinary racism] Milano, Italy: Baldini Castoldi Dalai editore S.p.A.

Knaus, C. (2009). Shut up and listen: Applied critical race theory in the classroom. Race, Ethnicity and Education, 12(2),133-154.

Kowalczyk, J., \& Popkewitz, T. S. (2005). Multiculturalism, recognition and abjection: (Re)mapping Italian identity. Policy Futures in Education, 3(4), 423-435. Retrieved from http://www.wwwords.co.uk/pdf/validate.asp?j $=$ pfie \&vol=3\&issue =4\&year=2005\&article=9_Kowalczyk_PFIE_3_4_web

Kubota, R., \& Lin, A. (2006). Race and TESOL: Introduction to concepts and theories. TESOL Quarterly, 40(3), 471-493.

Ladson-Billings, G. (2009). Just what is critical race theory and what's it doing in a nice field like education? In E. Taylor, D. Gillborn \& G. Ladson-Billings (Eds.), Foundations of Critical Race Theory in education (pp. 17-36). New York, NY: Routledge.

Lakhous, A. (2010, February 9). Permesso senza diritti [Residency without rights]. L'Unita. Retrieved from http://www.unita.it/italia/permessi-senzadiritti-1.34653

Leonardo, Z. (2009). Race, whiteness, and education. New York, NY: Routledge. 
Liddicoat, A., \& A. Diaz (2008). Engaging with diversity: The construction of policy for intercultural education in Italy. Intercultural Education, 19(2), 137-150.

Luatti, L. (2011). Mediatori atleti dell'incontro: luogi, modi e nodi della mediazione interculturale [Expert mediators of the encounter: Places, ways and nodes of intercultural mediation]. Gussago, Italy: Vannini Editrice Srl.

Malta, A. (2010). Seconda generazione: Una categoria utile per le future linee di ricerca in pedagogia interculturale? [Second generation: A useful category for future strands of research in intercultural pedagogy?] Quaderni di Intercultura, 2, 1-10.

Marinaro, I. C., \& Walston, J. (2010). Italy's 'second generations': The sons and daughters of migrants. Bulletin of Italian Politics, 2(1), 5-19.

Mills, C.W. (1997). The racial contract. Ithaca, NY: Cornell University Press.

Ministero della Pubblica Istruzione (2007). La via italiana per la suola interculturale e l'integrazione degli alunni stranieri: Osservatorio nazionale per l'integrazione degli alunni stranieri e per l'educazione interculturale [The Italian path for the intercultural school and the integration of foreign students: National observatory for the integration of foreign students and for intercultural education]. Romo, Italy: Ministero della Pubblica Instruzione.

Moschel, M. (2007/2008). Color blindness or total blindness? The absence of Critical Race Theory in Europe. Rutgers Race and the Law Review, 9(1), 57-127.

Moschel, M. (2011). Race in mainland European legal analysis: Towards a European critical race theory. Ethnic and Racial Studies, 34(10),16481664.

Moss, G. (2008). Diversity study circles in teacher education practice: An experimental learning project. Teacher and Teacher Education, 24, 216224.

Murie, A., \& Musterd, S. (2004). Social exclusion and opportunity structures in European cities and neighborhoods. Urban Studies, 41(8), 1441-1459.

Omi, M., \& Winant, H. (1994). Racial formation in the United States: From the 1960 s to the 1990s. New York, NY: Routledge.

Parati, G. (2005). Migration Italy: The art of talking back in a destination culture. Toronto, Canada: University of Toronto Press.

Peri, C. (2009). Integrazione: Un percorso accidentato [An accidental path]. In C. Peri (Ed.), L'italiano per l'intergrazione: Quaderno [The Italian for integration: Notebook] 7 (pp. 7-16). Romo, Italy: Associazione centro astalli per l'assistenze agli immigrati. 
Portelli, A. (2005). The problem of the color-blind. Notes on the discourse on race in Italy. In P.R. Spickard (Ed.), Race and nation: Ethnic systems in the modern world (pp. 355-364). New York, NY: Routledge.

Pratt, J. C. (2002). Italy: Political unity and cultural diversity. In J. C. Pratt \& R. D. Grillo (Eds.), The politics of recognizing difference: Multiculturalism Italian-style (pp. 25-40). Bashingstoke, UK: Ashgate.

Ricucci, R. (2008). Educating immigrant children in a 'newcomer' immigration country: A case study. Intercultural Education, 19(5), 449-460.

Romero, A., Arce, S., \& Cammarota, J. (2009). A Barrio pedagogy: Identity, intellectualism, activism, and academic achievement through the evolution of critically compassionate intellectualism. Race, Ethnicity and Education, 12(2), 217-233.

Sleeter, C. E., \& Delgado Bernal, D. (2004). Critical pedagogy, critical race theory, and antiracist education: Implications for multicultural education. In J. A. Banks \& C. A. M. Banks (Eds.), Handbook of research on multicultural education ( $2^{\text {nd }}$ ed., pp. 240-258). San Franscisco, CA: Jossey-Bass.

Stewart-Steinberg, S. (2007). The Pinocchio effect: On making Italians, 18601920. Chicago, IL: The University of Chicago Press.

Stovall, D., Lynn, M., Danley, L., \& Martin, D. (2009). Introduction: Critical race praxis in education. Race, Ethnicity and Education, 12(2), 131-132.

Taylor, E., Gillborn, D., \& Ladson-Billings, G. (2009). Foundations of critical race theory in education. New York, NY: Routledge.

Valentini, A. (2005). Lingue e interlingue dell'immigrazione in Italia [Language and interlanguage of Italian immigration]. Linguistica e Filologia, 21, 185206.

Valenzuela, A. (1999). Subtractive schooling: U.S.-Mexican youth and the politics of caring. New York, NY: State University of New York Press.

Woolard, K. A., \& Schieffelin, B. B. (1994). Language ideology. Annual Reviews in Anthropology, 23, 55-82.

Wong, A. S. (2006). Race and the nation in liberal Italy, 1861-1911: Meridionalism, empire, and diaspora. New York, NY: Palgrave Macmillan. 